\title{
Intermittent Energy Output
}

National Cancer Institute

\section{Source}

National Cancer Institute. Intermittent Energy Output. NCI Thesaurus. Code C133561.

Problem associated with the energy output from the device being inconsistent over time. 